\title{
The good, the bad, and the uncertain: Can matrix metalloproteinase 12 simultaneously be protumorigenic and antitumorigenic?
}

\author{
Laurence P. Diggs, MD, and R. Taylor Ripley, MD
}

\author{
From the Thoracic and Oncologic Surgery Branch, Center for Cancer Research, National Cancer Institute, Na- \\ tional Institutes of Health, Bethesda, Md. \\ Disclosures: Authors have nothing to disclose with regard to commercial support. \\ Received for publication Jan 1, 2018; accepted for publication Jan 6, 2018; available ahead of print Feb 1, 2018. \\ Address for reprints: R. Taylor Ripley, MD, Thoracic Surgeon, Thoracic and GI Oncology Branch, CCR/NCI, \\ Building 10, 4-3952, 10 Center Dr, MSC 1201, Bethesda, MD 20892-1201 (E-mail: Taylor.Ripley@nih.gov). \\ J Thorac Cardiovasc Surg 2018;155:2162-3 \\ 0022-5223/\$0.00 \\ Published by Elsevier Inc. on behalf of The American Association for Thoracic Surgery \\ https://doi.org/10.1016/j.jtcvs.2018.01.002
}

In this issue of the Journal, Ella and colleagues ${ }^{1}$ study the role of matrix metalloproteinase 12 (MMP-12) in lung cancer. Although MMP-12's relationship to chronic obstructive pulmonary disease and asthma is well documented, ${ }^{2-4}$ its role in non-small cell lung cancer (NSCLC) is contradictory. The relationship between MMP-12 overexpression in both chronic obstructive pulmonary disease and other malignancies has prompted several reports of MMP-12 and NSCLC. ${ }^{2,3,5-8}$ These studies have yielded remarkably conflicting results. On the one hand, higher MMP-12 expression has been shown to correlate with increased tumor growth, invasion, metastases, recurrence, and suppression of immune responses. ${ }^{9-11}$ On the other hand, other studies have demonstrated that MMP-12 may exert a protective effect by suppressing growth and metastases while modulating apoptosis. ${ }^{12-14}$ Both macrophages and tumor cells produce MMP-12, which may contribute to the opposing functions. ${ }^{10,14}$ Efforts to demonstrate the role of MMP-12 in NSCLC have fallen short.

Ella and colleagues ${ }^{1}$ demonstrate the tumorigenic effect of tumor-derived MMP-12 with insightful and original findings. First, they performed univariable and multivariate analyses of 3 lung cancer microarray data sets, cancer Biomedical Informatics Grid (caBIG), Gene Expression Omnibus (GEO), and The Cancer Genome Atlas (TCGA) and demonstrated that higher MMP-12 levels were associated with lower median overall survivals. As Ella and colleagues ${ }^{1}$ note, these conclusions merit caution given the retrospective findings and the inability to perform a comprehensive multivariate analysis. Importantly, a survival analysis per stage is not reported. With an immunohistochemical staining of a lung cancer tissue array, they observed higher expression of MMP-12 in nearly all NSCLC lung histologic types when compared with normal lung tissue. They stress that MMP-12 expression in all histologic types represents important additional knowledge on

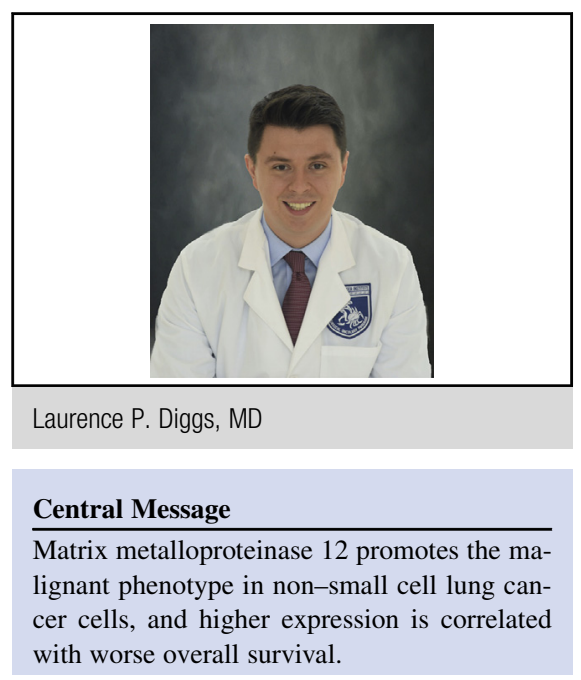

See Article page 2164. this topic; however, the array included only a small number of small cell, large cell, neuroendocrine, carcinoid tumors, and bronchoalveolar carcinoma.

Another particularly notable finding is that exposing tumor cells to lung microenvironment both in vitro and in vivo drives higher expression of tumor cell-derived MMP-12. These findings are consistent with previous experiments demonstrating that MMP-12 in tumors is primarily induced from stromal cells rather than macrophages. ${ }^{9-11}$ They also observe that knocking down MMP-12 both in vitro and in vivo decreased the malignant phenotype of the cells, as noted by a marked reduction in colony formation. In their in vivo model, they directly inject the lung to recapitulate early-stage lung cancer. Ideally, they would report whether MMP-12 was associated with different survivals among patients with stage I NSCLC, rather than grouping all stages, to be consistent with this model. In addition, tail vein injections to model metastatic colonization could strengthen the conclusions of MMP-12 in all stages of NSCLC, especially because they noted reports of no difference in recurrence according to MMP-12 expression. One final note is that most of the experiments were performed in a murine cell line (LLC) as well as one human-derived line from a large cell carcinoma (H460). Ideally, these experiments would be confirmed in adenocarcinoma or squamous cell carcinoma. Regardless of these limitations, Ella and colleagues ${ }^{1}$ are to be commended for 
reporting original and compelling evidence for the tumorigenic properties of MMP-12 in NSCLC. They have both used interesting models to study the endlessly complex tumor microenvironment and correlated these models with patient-derived data.

\section{References}

1. Ella E, Harel Y, Abraham M, Wald H, Benny O, Karsch-Bluman A, et al. Matrix metalloproteinase 12 promotes tumor propagation in the lung. J Thorac Cardiovasc Surg. 2018;155:2164-75.e1.

2. Hunninghake GM, Cho MH, Tesfaigzi Y, Soto-Quiros ME, Avila L, Lasky-Su J, et al. MMP12, lung function, and COPD in high-risk populations. $N$ Engl J Med. 2009;361:2599-608.

3. Demedts IK, Morel-Montero A, Lebecque S, Pacheco Y, Cataldo D, Joos GF, et al. Elevated MMP-12 protein levels in induced sputum from patients with COPD. Thorax. 2006;61:196-201.

4. Van Doren SR. Matrix metalloproteinase interactions with collagen and elastin. Matrix Biol. 2015;44-46:224-31.

5. Durham AL, Adcock IM. The relationship between COPD and lung cancer. Lung Cancer. 2015;90:121-7.

6. Van Nguyen S, Skarstedt M, Löfgren S, Zar N, Andersson RE, Lindh M, et al. Gene polymorphism of matrix metalloproteinase-12 and -13 and association with colorectal cancer in Swedish patients. Anticancer Res. 2013;33: 3247-50.
7. Shin A, Cai Q, Shu XO, Gao YT, Zheng W. Genetic polymorphisms in the matrix metalloproteinase 12 gene (MMP12) and breast cancer risk and survival: the Shanghai Breast Cancer Study. Breast Cancer Res. 2005;7:R506-12.

8. Valdivia A, Peralta R, Matute-González M, García Cebada JM, Casasola I, Jiménez-Medrano C, et al. Co-expression of metalloproteinases 11 and 12 in cervical scrapes cells from cervical precursor lesions. Int J Clin Exp Pathol. 2011;4: 674-82.

9. Qu P, Yan C, Du H. Matrix metalloproteinase 12 overexpression in myeloid lineage cells plays a key role in modulating myelopoiesis, immune suppression, and lung tumorigenesis. Blood. 2011;117:4476-89.

10. Hofmann HS, Hansen G, Richter G, Taege C, Simm A, Silber RE, et al. Matrix metalloproteinase-12 expression correlates with local recurrence and metastatic disease in non-small cell lung cancer patients. Clin Cancer Res. 2005;11: 1086-92.

11. Lv FZ, Wang JL, Wu Y, Chen HF, Shen XY. Knockdown of MMP12 inhibits the growth and invasion of lung adenocarcinoma cells. Int J Immunopathol Pharmacol. 2015;28:77-84.

12. Houghton AM, Grisolano JL, Baumann ML, Kobayashi DK, Hautamaki RD Nehring LC, et al. Macrophage elastase (matrix metalloproteinase-12) suppresses growth of lung metastases. Cancer Res. 2006;66:6149-55.

13. Dandachi N, Kelly NJ, Wood JP, Burton CL, Radder JE, Leme AS, et al. Macrophage elastase induces TRAIL-mediated tumor cell death through its carboxyterminal domain. Am J Respir Crit Care Med. 2017;196:353-63.

14. Acuff HB, Sinnamon M, Fingleton B, Boone B, Levy SE, Chen X, et al. Analysis of host- and tumor-derived proteinases using a custom dual species microarray reveals a protective role for stromal matrix metalloproteinase-12 in non-smal cell lung cancer. Cancer Res. 2006;66:7968-75. 